Original Research Paper

\title{
Design and Implementation of Optimum Management System using Cost Evaluation and Financial Analysis for Prevention of Building Failure
}

\author{
Nima Amani \\ Department of Civil Engineering, Chalous Branch, Islamic Azad University, Chalous, Iran
}

Article history

Received: 28-05-2015

Revised: $14-03-2016$

Accepted: 19-03-2016

Email: nimaamani@iauc.ac.ir

\begin{abstract}
Building management is complex as the implementation of the engineering management system and is subjected to require the top management for supporting the construction industry. To achieve this management must use a system to control the preventive management of building failure. The purpose of the paper is to develop a new approach to optimize the management process for systematic prevention of building failure. To optimum the management of building elements and equipments, the data from 4 case studies are used. These data are analyzed by computation of financial and economical systems. For building managers seeking to expand their knowledge of a particular process or preventive management systems in general, the paper provides a practical understanding. The process developed in this research will help firms of engineering/managing with a reliable implementation tool for their buildings installation and this will promote engineering management development.
\end{abstract}

Keywords: Engineering Management, Case Study, Building Management, Cost Evaluation, Process Analysis

\section{Introduction}

The most important issue of successful component maintenance activities is a suitable cost allocated to a project. One of the reasons for change in component maintenance management and planning is due to the limited allocation of cost (Boyle, 2003). Furthermore, lack of suitable cost allocation in a component maintenance work can affect the maintenance implementation (Tilley and McFallen, 2000). Therefore building managers or owners are responsible for management and allocation of maintenance costs for good maintenance outcomes.

Quality of maintenance works on the building components is dependent on the amount of cost allocation in this sector. Sufficient capital includes staffing, inspecting and financials which are required for components maintenance works in the buildings (Lee and Scott, 2009). Maintenance and repair planning for upgrading components and material conditions in the building need regularly programmed condition assessment. These inspections and assessments should be designed and classified by inspectors and engineers. This goal needs the inspector of the components and elements to provide suitable information for the computation of a condition assessment. Lack of information and knowledge about the important building component can result in mismanagement in the field of components maintenance and can affect increasing cost of building and building age reduction. A comprehensive process should be established for monitoring the most important building component. A literature review on previous research indicates that there are issues of cost and planning optimization of components maintenance (Boyle, 2003; Mohd-Noor et al., 2011; Ali, 2009; Lam et al., 2010). Eventually, the limited budget must be used for the most important components and materials in buildings. The objective of this study is to develop a new model to optimize the management of public building facilities using the Condition Category Guides (CCG) as a measurement method.

\section{Scope of the Study}

The analysis is done on the waste-water installation system of four hotels in Tehran. The material used for waste-water systems is cast iron pipes. The analysis will 
be done on the waste-water networks of five-star hotels in Tehran. Instances will show how a best time approach to waste-water networks maintenance can help the owner with decision making regarding component maintenance time based on existing costs. This system controls existing budget in part of component maintenance and increases component service life and, finally, prevents early deterioration and wastewater plumbing systems replacement in four- and five-stars hotel buildings in Tehran (capital of Iran).

The scope is highlighted by the Tehran Area Hotel Union (TAHU), which is the largest hotel union in Iran. The TAHU divided the Tehran area into three smaller areas: North $(\mathrm{N})$, Centre $(\mathrm{C})$, and East $(\mathrm{E})$. As shown in Fig. 1, the north area consists of five hotels, while the east area has only one hotel. The largest number of hotels is in centre area which includes 15 hotels.

Presently, the condition of hotel buildings in Tehran, including four- and five-star hotels, is continuous altering- that is, declining- for the following reasons:

- Age: The average age of four- and five-star hotels in Iran is more than 30 years old (TAHU, 2011)

- Tourist capacity: Presently, four- and five-star hotels in Iran are encountering extra pressure due to the lack of hotels with luxury class and first class in the country. This pressure will be increased with passing time, increasing population and tourism industry development, that puts great pressure on hotel components maintenance and repair programmes

- Incompetent maintenance: Research has shown that, in Iran, more than $30 \%$ of five-star hotels need to be repaired or upgraded to good comprehensive condition (Farokhmehr, 2009)

\section{Limitation within the Building Component Maintenance Management Domain}

In reviewing the available literature on the maintenance management of building components, there is a lack of strategy of the maintenance of the building component based on limited cost can result in an inefficient usage of the scarce resources available for maintenance (renewal, service, inspecting, repairing, replacement, etc.). Maintenance cost allocation monitoring at the component level can provide much needed information to the facilities manager and owner about the building components; a methodology for monitoring the important building components with respect to the sensitive condition of components in a building; a methodology for determining the appropriate assessment method of building components and forecasting component future conditions; and a decision support tool that can use the collected data to assist the building manager and owner to make meaningful maintenance management decisions regarding the continued usage of the components and materials.

\section{The Case Study}

This part identifies the important building component with respect to defects and indications and its effect on clients, staff and users of building. First, the top nine building components include interior surface, exterior surface, mechanical system, electrical system, communication system, clean water system, waste-water plumbing system, structural system and roof were identified through the literature and through discussion with engineers and inspectors in the industry (Arditi and Nawakorawit, 1999). Second, information that is related to the sensitivity of the building components was collected from a large owner organization, the Iranian Society of Consulting Engineers (ISCE). A comprehensive survey was then performed between experienced personnel at the ISCE in order to understand the various problems of component and statistics related to difficult percentages of replacing, repairing, cleaning and inspecting among components. The respondents indicated the most difficult to replace, clean and inspect associated with the selected building component, which was derived through a questionnaire. This methodology is a quantitative method and formed the background information for the selected component described.

\section{The Analysis of the Selection of Waste-water Plumbing System as the Most Important Component}

In May 2010 a survey was conducted on the largest 100 building Companies in the Iran to investigate the problems related to Component Condition Assessment (CCA) science of buildings. Questionnaires were distributed in big cities of Iran including Tehran, Isfahan and Yazd. The findings identified the level of difficulty in cleaning, inspecting, repairing and replacing various building components. Statistical analysis shows that the three most difficult components to repair and replace that were indicated by the respondents are the mechanical system, the waste-water system and the electrical system, as shown in Fig. 2. The waste-water plumbing system appears to be one of the major areas of difficulty because it was ranked by the assessors and engineers.

Assessments show that mismanagement in maintenance of waste-water plumbing affects the increasing cost of building and reducing building's age. Most firms were faced with this kind of problem concerning repair of waste-water plumbing includes reproductive equipment, heat equipment, fittings equipment and transfer equipment and distribution. 


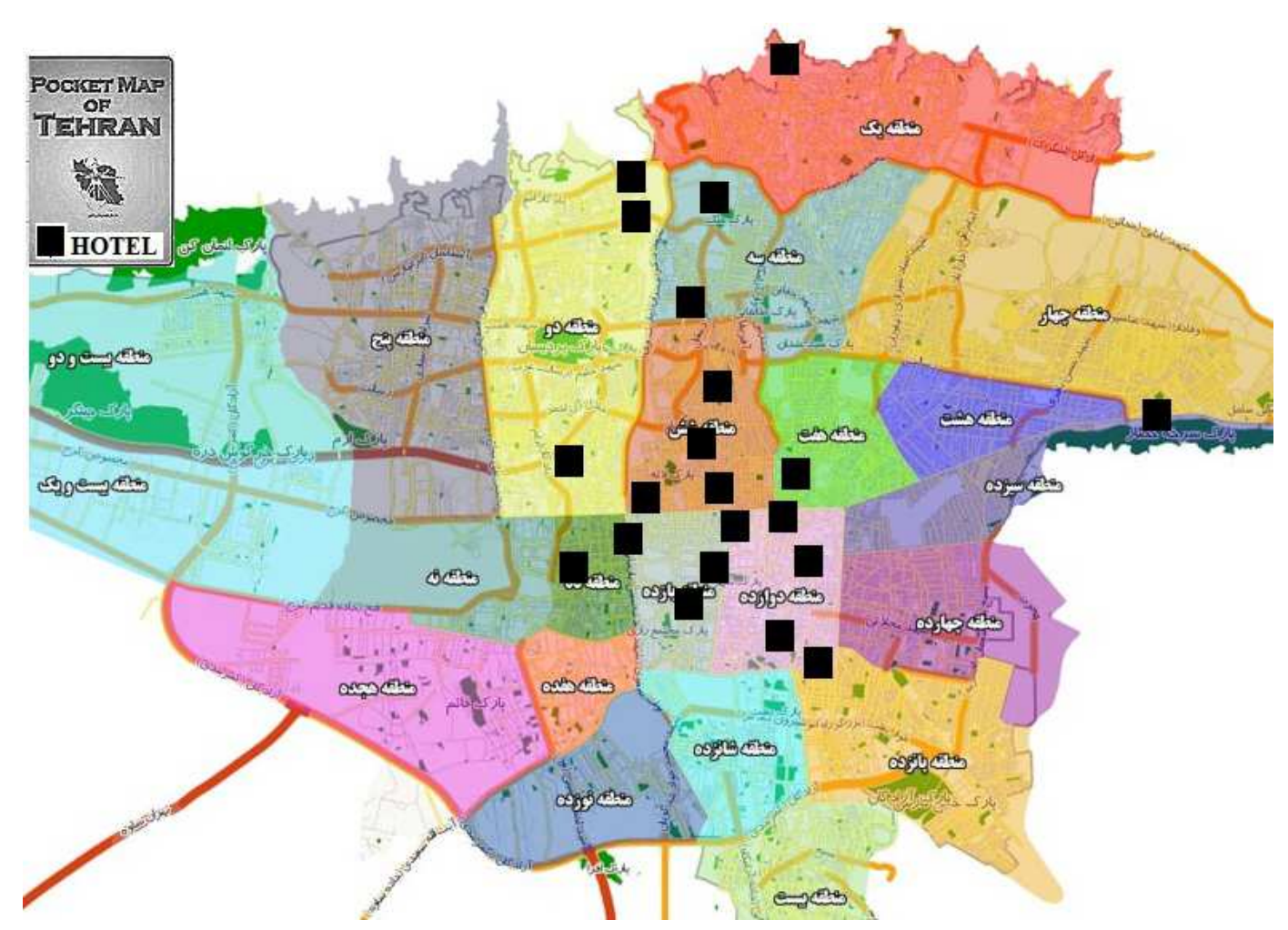

Fig. 1. Locations of the hotels at the TAHU (2011)

\section{Repairing \& Replacing}

= Repairing \& Replacing

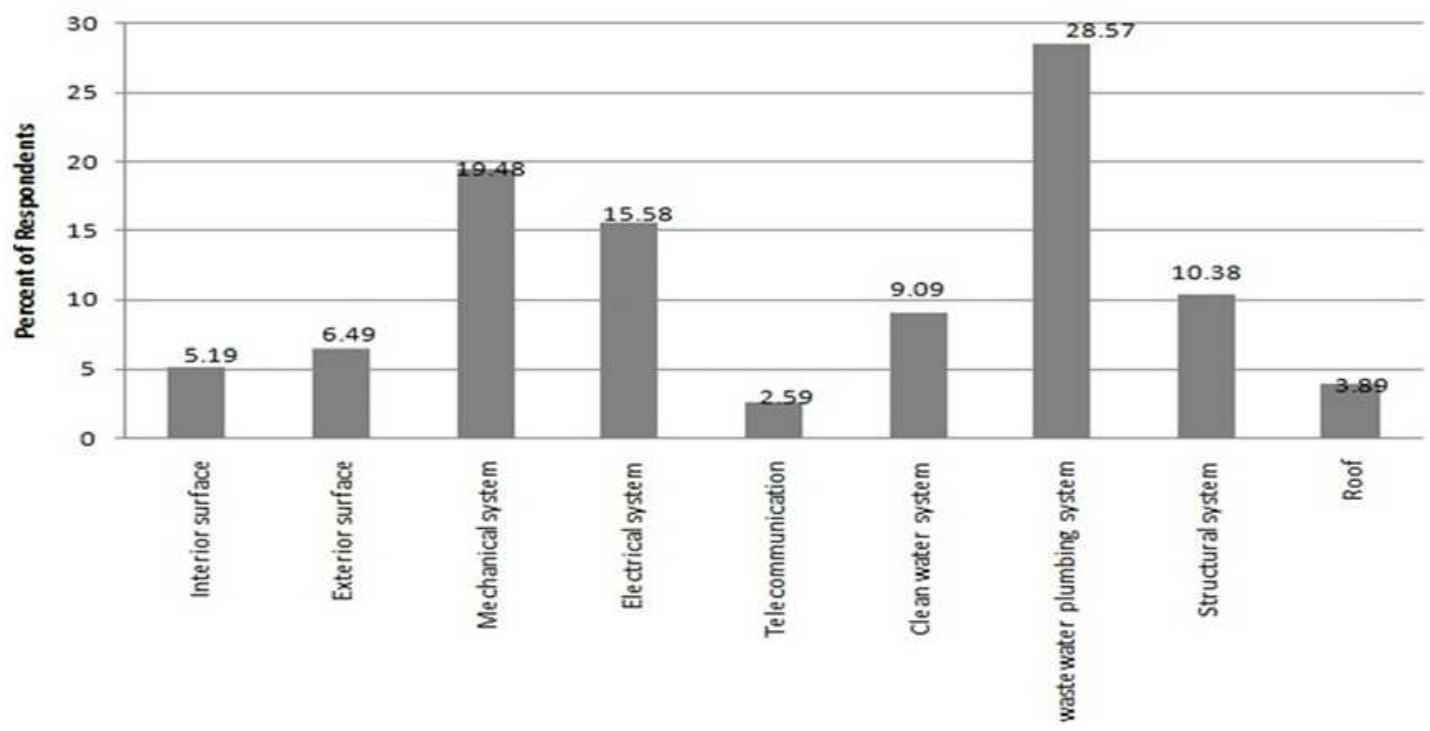

Fig. 2. Difficulties of building component maintenance (repairing, replacing, inspecting, cleaning and other activities) (Amani et al., 21012)

In addition, the ISCE personnel reported that, for technical reasons, the plumbing system, which is part of the waste-water service, there is the most important in the case of hotels. Other findings related to ISCE by Amani et al. (2012) that investigated the comparative effect of a component's failure on cost and safety 
building activities and on other components, verified the importance of the waste-water plumbing system, as it obtained the highest score. Based on these reasons, the plumbing system was selected for this research: Cast iron pipes in waste-water systems.

\section{Component Condition Assessment System (CCAS)}

USACERL (Uzarski, 1993) has been developed by the U.S. Army corps engineers at the Engineering Research and Development Center. Construction Engineering Research Laboratories (CERL) in plain. This method supports engineers, assessors and component managers with a toll that provides decisions regarding when and where is the best to maintain and repair buildings and their key components. USACERL condition index method is condition-based with functions which comprise an asset of major building components; condition indices; condition prediction skill; and comprehensive condition description for each CI value (Builder, 2008). The USACERL condition indices were designed to support a purpose and quantitative means for component condition assessment while supporting and assessors. The scale used in all of the USACERL indices ranges from 0 to 100 and is divided into seven condition categories (Table 1). This method is used for every component in a building system or non-building system. This method has a comprehensive condition description for assessing component condition (Table 1); predicting the future component condition; and predicting the suitable time for repair and maintenance. This model is extendable, as it has amplitude 0 to 100 . Namely, each range has a domain. For example, (100-85), (85-70), ... and (10-0). Therefore, component with long service life can use this method by selecting more properties. In fact, it can have one hundred properties for assessment of component.

\section{Research Methodology}

This comprehensive study surveys hotel area repair and maintenance suitability through analysis of technical resource models, financial plan (budget), structured and unstructured estimates and direct field observation within hotels and hotel areas from the standpoint of engineers and installation inspectors with more than 30 years experience in the field of piping system inspection and repairs in Tehran.

The Building Component Assessment Process (BCAP) was developed in three main stages:

- Stage 1: Data collection

- $\quad$ Stage 2: Data analysis
- $\quad$ Stage 3: Verification of data analysis

\section{Stage 1: Data Collection-Technical and Financial Information}

Stage I, involves gathering of information and data on existing practices from two levels of sources, technical and financial. Two information gathering techniques used were questionnaires and interviews. Documents analyzed include engineers and inspectors' experiences and knowledge and financial reports. Thirty installation companies and four hotels were included in the questionnaire and interview samples respectively.

The technical data was collected based on engineers and inspectors' experiences and knowledge. This sheet was distributed among inspectors and engineers for collecting and computing component repair time during its service life over time. Technical data instruction is method of rating and determination of maintenance time of component in its service life based on condition category guidelines. The rating panel that contributed to this development is formed through contractors firms and related consultants with the component of public building. These panels are 30 installation consultant firms. As depicted in Table 2, this data is to achieve the information related to the maintenance time of cast iron pipe from stand point of engineers and inspectors' experiences in past years with respect to the moving the index from 100 to 0 during components' service life. These data (maintenance year) will be used for analysis research case studies in this study. Each firm has predicted the times of cast iron pipe maintenance in waste-water system based on CCG from index 85 to index 10 . The maintenance times are based on a period of 50 years that corresponds to the service life of cast iron pipes in waste-water plumbing systems which is approximately 50 years (HOAM, 1993). These predictions were done based on $\mathrm{CCG}$ condition discretion as a guide and the engineer's experiences. After a given set of sheets was completed, the researcher has reviewed the data during the session. The rating average was computed in each condition index value. Next, the process of standard deviation was calculated in each condition index $(85,70,55,40$ and 25) from rating corrections and accurate responses by engineers and assessors. Any rating that is more than the required standard deviation in each index value from the average was flagged for a rerate. When the re-rate process was done (re-rate in Table 2), researcher computed the average of responses in each index value. These averages are the maintenance year during service life of cast iron pipe. 
Nima Amani / American Journal of Engineering and Applied Sciences 2016, 9 (2): 281.296 DOI: 10.3844/ajeassp.2016.281.296

Table 1. Condition Category Guidelines (CCG)

\begin{tabular}{|c|c|c|c|c|}
\hline \multirow{2}{*}{$\begin{array}{l}\text { Condition } \\
\text { rating }\end{array}$} & \multirow[b]{2}{*}{ Category } & \multicolumn{3}{|l|}{ Condition description } \\
\hline & & Amount of distress & Functionality & Type of M\&R \\
\hline $71-85$ & Very good & Minor deterioration & Slightly impaired & $\begin{array}{l}\text { Preventive or minor } \\
\text { maintenance, or minor repair }\end{array}$ \\
\hline $56-70$ & Good & Moderate deterioration & Somewhat impaired & $\begin{array}{l}\text { Moderate maintenance or } \\
\text { minor repair }\end{array}$ \\
\hline $41-55$ & Fair & Significant deterioration & Seriously impaired & $\begin{array}{l}\text { Significant maintenance or } \\
\text { moderate repair }\end{array}$ \\
\hline $26-40$ & Poor & $\begin{array}{l}\text { Server deterioration over small } \\
\text { portion of sample unit }\end{array}$ & Critically impaired & Major repair \\
\hline $11-25$ & Very Poor & $\begin{array}{l}\text { Server deterioration over } \\
\text { moderate portion of sample unit }\end{array}$ & Barely exists & $\begin{array}{l}\text { Major repair but less than } \\
\text { total restoration }\end{array}$ \\
\hline $0-10$ & Failed & $\begin{array}{l}\text { Server deterioration over large } \\
\text { portion of sample unit }\end{array}$ & Lost & Total restoration \\
\hline
\end{tabular}

Table 2. Technical data collection and re-rate based on CCG

\begin{tabular}{|c|c|c|c|c|c|c|c|c|c|c|c|c|c|}
\hline \multirow{2}{*}{$\begin{array}{l}\text { Firms no. } \\
\text { Index }\end{array}$} & \multirow[b]{2}{*}{85} & \multirow[b]{2}{*}{70} & \multirow[b]{2}{*}{55} & \multirow[b]{2}{*}{40} & \multirow[b]{2}{*}{25} & \multirow[b]{2}{*}{10} & \multirow{2}{*}{$\begin{array}{l}\text { Firms no. } \\
\text { Index }\end{array}$} & \multicolumn{5}{|c|}{ Rerate } & \multirow[b]{2}{*}{10} \\
\hline & & & & & & & & 85 & 70 & 55 & 40 & 25 & \\
\hline$\overline{1}$ & 8.0 & 15.0 & 24.0 & 32 & 41.0 & 50 & 1 & & & & 33.0 & 42.0 & \\
\hline 2 & 5.0 & 18.0 & 29.0 & 38 & 45.0 & 50 & 2 & 7 & & & & & \\
\hline 3 & 9.0 & 13.0 & 22.0 & 37 & 40.0 & 50 & 3 & & 15.0 & 23.0 & & 42.0 & \\
\hline 4 & 5.0 & 15.0 & 26.0 & 30 & 42.0 & 50 & 4 & 8 & & & 33.0 & & \\
\hline 5 & 8.0 & 12.0 & 21.0 & 34 & 41.0 & 50 & 5 & & 15.0 & 23.0 & & 42.0 & \\
\hline 6 & 8.0 & 18.0 & 27.0 & 37 & 45.0 & 50 & 6 & & & & & & \\
\hline 7 & 9.0 & 16.0 & 26.0 & 36 & 41.0 & 50 & 7 & & & & & 42.0 & \\
\hline 8 & 10.0 & 17.0 & 27.0 & 33 & 45.0 & 50 & 8 & & & & & & \\
\hline 9 & 11.0 & 19.0 & 26.0 & 33 & 44.0 & 50 & 9 & & & & & & \\
\hline 10 & 9.0 & 21.0 & 29.0 & 37 & 44.0 & 50 & 10 & & 19.0 & & & & \\
\hline 11 & 8.0 & 15.0 & 28.0 & 36 & 46.0 & 50 & 11 & & & & & & \\
\hline 12 & 11.0 & 22.0 & 34.0 & 39 & 45.0 & 50 & 12 & & 19.0 & 30.0 & & & \\
\hline 13 & 9.0 & 16.0 & 22.0 & 31 & 42.0 & 50 & 13 & & & 23.0 & & & \\
\hline 14 & 10.0 & 21.0 & 34.0 & 39 & 44.0 & 50 & 14 & & 19.0 & 30.0 & & & \\
\hline 15 & 9.0 & 17.0 & 28.0 & 38 & 45.0 & 50 & 15 & & & & & & \\
\hline 16 & 6.0 & 15.0 & 24.0 & 37 & 42.0 & 50 & 16 & 7 & & & & & \\
\hline 17 & 9.0 & 18.0 & 21.0 & 35 & 43.0 & 50 & 17 & & 23.0 & & & & \\
\hline 18 & 7.0 & 14.0 & 20.0 & 34 & 45.0 & 50 & 18 & & 15.0 & 23.0 & & & \\
\hline 19 & 6.0 & 16.0 & 29.0 & 37 & 44.0 & 50 & 19 & 8 & & & & & \\
\hline 20 & 10.0 & 17.0 & 26.0 & 38 & 44.0 & 50 & 20 & & & & & & \\
\hline 21 & 9.0 & 18.0 & 25.0 & 33 & 41.0 & 50 & 21 & & & & & 42.0 & \\
\hline 22 & 11.0 & 19.0 & 28.0 & 36 & 46.0 & 50 & 22 & & & & & & \\
\hline 23 & 12.0 & 25.0 & 32.0 & 39 & 47.0 & 50 & 23 & & 19.0 & 30.0 & & 45.0 & \\
\hline 24 & 10.0 & 20.0 & 33.0 & 39 & 44.0 & 50 & 24 & & 19.0 & 30.0 & & & \\
\hline 25 & 8.0 & 16.0 & 27.0 & 38 & 46.0 & 50 & 25 & & & & & & \\
\hline 26 & 6.0 & 14.0 & 22.0 & 34 & 45.0 & 50 & 26 & 7 & 15.0 & 23.0 & & & \\
\hline 27 & 11.0 & 17.0 & 28.0 & 29 & 44.0 & 20 & 27 & & & & & & \\
\hline 28 & 8.0 & 16.0 & 26.0 & 34 & 41.0 & 50 & 28 & & & & & 42.0 & \\
\hline 29 & 10.0 & 19.0 & 28.0 & 39 & 46.0 & 50 & 29 & & & & & & \\
\hline 30 & 9.0 & 17.0 & 25.0 & 38 & 44.0 & 50 & 30 & & & & & & \\
\hline Average & 8.7 & 17.0 & 26.5 & 36 & 43.8 & 50 & Average & 9 & 16.9 & 26.5 & 36.1 & 43.9 & 50 \\
\hline $\begin{array}{l}\text { Standard } \\
\text { division }\end{array}$ & 2.0 & 2.5 & 3.5 & 3 & 2.0 & - & & & & & & & \\
\hline
\end{tabular}

Table 3 shows the maintenance year data based on Condition Category Guidelines (CCG). Maintenance year has been predicted by engineers and inspectors in 30 firms based on the condition description column as a guide and engineers' experiences over the past years. This prediction is based on the period of 50 years (service life of cast iron pipe) with respect to moving the index from 100 to 10 during service life of cast iron pipe. For example, engineers predicted the cast iron pipe needs routine maintenance or minor repair after 36 years (index 40) and the waste-water plumbing system needs major repair after 43 year (index 25 ). 
Nima Amani / American Journal of Engineering and Applied Sciences 2016, 9 (2): 281.296 DOI: 10.3844/ajeassp.2016.281.296

Table 3. Data collection of maintenance predictive year based on CCG

\begin{tabular}{|c|c|c|c|c|c|}
\hline \multirow[b]{2}{*}{$\begin{array}{l}\text { Condition } \\
\text { rating }\end{array}$} & \multirow[b]{2}{*}{ Category } & \multirow[b]{2}{*}{$\begin{array}{l}\text { Maintenance } \\
\text { year }\end{array}$} & \multicolumn{3}{|l|}{ Condition description } \\
\hline & & & Amount of distress & Functionality & Type of M\&R \\
\hline $71-85$ & Very Good & 9.0 & Minor deterioration & Slightly impaired & $\begin{array}{l}\text { Preventive or minor } \\
\text { maintenance, or minor repair }\end{array}$ \\
\hline $56-70$ & Good & 16.9 & Moderate deterioration & Somewhat impaired & $\begin{array}{l}\text { Moderate maintenance or } \\
\text { minor repair }\end{array}$ \\
\hline $41-55$ & Fair & 26.5 & Significant deterioration & Seriously impaired & $\begin{array}{l}\text { Significant maintenance or } \\
\text { moderate repair }\end{array}$ \\
\hline $26-40$ & Poor & 36.1 & $\begin{array}{l}\text { Server deterioration over small } \\
\text { portion of sample unit }\end{array}$ & Critically impaired & Major repair \\
\hline $11-25$ & Very Poor & 43.9 & $\begin{array}{l}\text { Server deterioration over } \\
\text { moderate portion of sample unit }\end{array}$ & $\begin{array}{l}\text { Barely exists } \\
\text { total restoration }\end{array}$ & Major repair but less than \\
\hline $0-10$ & Failed & 50.0 & $\begin{array}{l}\text { Server deterioration over large } \\
\text { portion of sample unit }\end{array}$ & Lost & Total restoration \\
\hline
\end{tabular}

Financial information is related to the annual maintenance cost allocated for waste-water plumbing system in hotels that is analyzed through data collection by financial managers. Financial sheet was designed based on the data gathering process covering annual cost information for maintenance of waste-water piping system in hotel building. The financial information is in two situations of historical and predictive data. In this study, financial managers fill financial information from 1990 to 2009 for historical data (existing financial documents) and from 2011 to 2060 for predictive data. The historical data was collected for annual maintenance cost allocated at various condition index values for the cast iron pipe component in the wastewater plumbing system based on maintenance cost information in past 20 years. The predictive data is selected based on period of 50 years that corresponds to the useful lifespan of cast iron pipe which is approximately 50 years (HOAM, 1993) using the prediction process and the average inflation rate computed from 1990 to 2009.

\section{Stage 2: Data Analysis}

The process was developed through calculations and simulation based on existing data and information. These calculations include four steps and were done in MS Excel software:

- Step 1: Calculation of saving estimate;

- Step 2: Calculation of replacement cost estimate

- Step 3: Calculation of repair cost estimate

- Step 4: Financial analysis

\section{Step 1: Calculation of Saving Estimate}

The saving is computed based on the maintenance cost allocated for service, repair, inspection and clean annually in part of component maintenance until year i. The saving is estimated based on Condition Category Guidelines (CCG) and maintenance year (technical data) for waste-water plumbing system in hotels through the following formula:

Saving calculation for predictive data:

$$
\left[\sum_{i=2011}^{n} F I_{i}\right]
$$

Where:

$F I=$ Financial information

$n=$ Year-end of annual maintenance cost in desired index (index 85 to index 10)

Saving calculation for historical data:

$\left[\sum_{i=1990}^{n} F I_{i}\right]$

Where:

$F I=$ Financial information

$n=$ Year-end of annual maintenance cost in desired index (index 85 to index 10)

\section{Step 2: Calculation of Replacement Cost Estimate}

The unit replacement cost is according to the current price of pipe in the Iran's market. The replacement cost is calculated based on dimension of waste-water plumbing system (size and length) of hotels, price of cast iron pipe in the Iran's market and average inflation rate for calculation of predictive data. The predictive data is calculated with inflation rate of $8 \%$ based on average inflation rate of cast iron pipe in Iran's market from 2000 to 2010 (Index Mundi, 2011; Price Index, 2011). The replacement cost is based on price index in Iran and including labor cost, transportation cost and the total cost of works (Price index, 2011). The replacement cost is estimated through following formula:

$R p c=L p \times C p$ 
Where:

$R p c=$ Replacement cost in desired year

$L p \quad=$ Length of pipe

$C p=$ Cost based on $\$ / \mathrm{m}$

\section{Step 3: Calculation of Repair Cost Estimate}

Repair cost is computed based on a standard equation. From these CI values, a parametric model of material repair cost, which is a comprehensive estimation of the corrective repair cost, is described as a percentage of the total replacement cost. Repair and maintenance calculations are based on American Society of Engineers formulas (Lazarus, 2012). There are other studies in the field of repair cost computations including Sajadi and Moghadam (2005) and RSMC, (2008). This section defines the repair cost using the existing statistics of construction industry. The repair cost is analyzed by using the economic techniques and financial issues in repair and maintenance based on existing definitions. This equation is linear and using the virtual variable:

$R c=R p c *(100-N / 90)$

Where:

$R c=$ Estimated unit repair cost in year $i$

$R p c=$ Estimated unit replacement cost in year $i$

$N=$ Desired condition index in situations of 10 to 100

\section{Step 4: Financial Analysis and Simulation}

Financial analysis is computed based on the benefit to cost ratio for optimum maintenance cost at various condition index values for the cast iron pipe in the wastewater plumbing system in hotels. Benefit to Cost Ratio (BCR) analysis is a technique for estimating a project or investment by comparing the economic benefits with the economic costs of the activity. BCR analysis has several objectives. First, BCR can be used to estimate the economic value of a project. Second the results from a series of BCR analyses can be used to compare competing projects (Ruegg and Marshall, 1990). The $\mathrm{BCR}$ is the benefit to cost ratio method recast to fit the situation that an investment's primary advantage is lower costs. BCR system illustrates that a ratio less than 1.0 indicates an uneconomical investment; a ratio of 1.0 Indicates an investment that benefits or savings just equal its costs; and a ratio greater than 1.0 illustrates an economic project. BCR is Comparison of the present value of an investment decision or project with its initial cost. Researchers can use BCR to combine interdependent building systems whether or not there is a budget constraint. But a primary application of BCR is the set funding priorities among projects when there is a limited budget. BCRs can guide the allocation of limited budgets among competing building components investments (Ruegg and Marshall, 1990). Benefit is computed based on total annual maintenance cost allocated for cast iron pipe per year until repair time at year $i$ based on saving estimation for waste-water network of hotels (step 1). Also, for a maintenance performance, the cost is the parametric evaluation of repair cost based on the condition index at year $i$ (step 3 ). The data, information and calculations are implemented based on value of money and inflation rate computed of Iranian Rials currency ( 1 IRR $=0.0001$ USD). To account for the time value of money, an inflation rate is used in this analysis for financial data of each hotel in saving estimation and an inflation rate of $8 \%$ for replacement cost in cost estimation. All benefits and costs are expressed in discounted present value terms. The BCR is calculated with following equation:

$$
B C R=\text { Benefit } / \text { Cost }
$$

Where:

Benefit $=$ Total annual maintenance budget until repair time

$\operatorname{Cost}(\$)=$ Repair cost in the year $i$

\section{Analysis of Case Studies}

The process is tested in four steps for four case studies. These steps is analyzed and simulated in two situations of historical and predictive data for each casestudy. The purpose of data analysis in two situations of historical and predictive data was the verification of data analysis. This model is for the prediction of optimum maintenance time of the waste-water network in hotel buildings with respect to the limited cost allocated to the department of component maintenance. If the optimum condition index is the same in two situations of historical and predictive data, it implies the workable capability of the process for accurate prediction in the future. The analysis results show that the process was tested for all case studies one by one.

In the verification of data analysis process, at first, the historical data have been considered and run for each case study and then the predictive data will be run in the process. In the next stage, the simulated results are compared in situations of historical and predictive data together. If the optimum condition index and also ascending and descending diagrams of condition indices are the same in two situations of historical and predictive data, it results in a workable process. Table 4 shows the pipe dimension information for waste-water network of case studies.

\section{Analysis of Historical Data}

Table 5 shows the financial historical data for case studies in the past 20 years. The financial information is related to the annual maintenance cost allocated for waste-water plumbing system in hotel buildings that 
were collected through gathering data by financial managers. In this table, annual maintenance costs are approximately 0 for first three years of operation in waste-water network of hotels from 1990 to 1992 because the maintenance cost is 0 approximately in first years. This information is based on existing financial documents in case studies.
Step 1 is calculation of financial historical data to achieve the saving estimate. The saving is calculated based on the budget collected for maintenance annually in part of component inspection until year i. The saving is estimated based on CCG condition index and maintenance year (accidental) for waste-water plumbing system in case studies (Table 6).

Table 4. Pipe dimension data of case studies

\begin{tabular}{|c|c|c|c|c|c|c|}
\hline Case Study 1 & Diameter (inch) & 2 & 3 & 4 & 5 & 6 \\
\hline \multirow{3}{*}{ Case Study 2} & Length (m) & 1100 & 750 & 650 & 200 & 150 \\
\hline & Diameter (inch) & 2 & 3 & 4 & 5 & 6 \\
\hline & Length (m) & 1300 & 850 & 800 & 200 & 150 \\
\hline \multirow[t]{2}{*}{ Case Study 3} & Diameter (inch) & 2 & 3 & 4 & 5 & 6 \\
\hline & Length (m) & 1000 & 600 & 750 & 300 & 150 \\
\hline \multirow[t]{2}{*}{ Case Study 4} & Diameter (inch) & 2 & 3 & 4 & 5 & 6 \\
\hline & Length (m) & 3200 & 2500 & 2700 & 600 & 400 \\
\hline
\end{tabular}

Table 5. Financial historical data for case studies

\begin{tabular}{|c|c|c|c|c|c|c|c|c|c|c|}
\hline & Year & $\begin{array}{l}\text { Annual } \\
\text { maintenance } \\
\text { cost }(\$)\end{array}$ & Year & $\begin{array}{l}\text { Annual } \\
\text { maintenance } \\
\text { cost }(\$)\end{array}$ & Year & $\begin{array}{l}\text { Annual } \\
\text { maintenance } \\
\text { cost }(\$)\end{array}$ & Year & $\begin{array}{l}\text { Annual } \\
\text { maintenance } \\
\text { cost }(\$)\end{array}$ & Year & $\begin{array}{l}\text { Annual } \\
\text { maintenance } \\
\text { cost }(\$)\end{array}$ \\
\hline \multirow[t]{4}{*}{ Case Study 1} & 1990 & - & 1994 & 1700 & 1998 & 3000 & 2002 & 4500 & 2006 & 5600 \\
\hline & 1991 & - & 1995 & 2300 & 1999 & 3300 & 2003 & 4700 & 2007 & 5800 \\
\hline & 1992 & - & 1996 & 2500 & 2000 & 3800 & 2004 & 4900 & 2008 & 5900 \\
\hline & 1993 & 1400 & 1997 & 2700 & 2001 & 4100 & 2005 & 5200 & 2009 & 6100 \\
\hline \multirow[t]{4}{*}{ Case Study 2} & 1990 & - & 1994 & 2000 & 1998 & 3600 & 2002 & 5100 & 2006 & 6500 \\
\hline & 1991 & - & 1995 & 2500 & 1999 & 3900 & 2003 & 5400 & 2007 & 6800 \\
\hline & 1992 & - & 1996 & 2800 & 2000 & 4200 & 2004 & 5800 & 2008 & 7200 \\
\hline & 1993 & 1600 & 1997 & 3200 & 2001 & 4700 & 2005 & 6200 & 2009 & 7600 \\
\hline \multirow[t]{4}{*}{ Case Study 3} & 1990 & - & 1994 & 1000 & 1998 & 2000 & 2002 & 2700 & 2006 & 3900 \\
\hline & 1991 & - & 1995 & 1100 & 1999 & 2200 & 2003 & 2900 & 2007 & 4200 \\
\hline & 1992 & - & 1996 & 1300 & 2000 & 2400 & 2004 & 3300 & 2008 & 4650 \\
\hline & 1993 & 800 & 1997 & 1800 & 2001 & 2500 & 2005 & 3600 & 2009 & 5000 \\
\hline \multirow[t]{4}{*}{ Case Study 4} & 1990 & - & 1994 & 5100 & 1998 & 7900 & 2002 & 10600 & 2006 & 13000 \\
\hline & 1991 & - & 1995 & 5900 & 1999 & 8700 & 2003 & 11200 & 2007 & 13800 \\
\hline & 1992 & - & 1996 & 6500 & 2000 & 9200 & 2004 & 11700 & 2008 & 14700 \\
\hline & 1993 & 4300 & 1997 & 7000 & 2001 & 9900 & 2005 & 12100 & 2009 & 15600 \\
\hline
\end{tabular}

Table 6. Computation of saving estimate in situation of historical data

\begin{tabular}{|c|c|c|c|c|c|c|}
\hline \multicolumn{7}{|l|}{ Historical data } \\
\hline $\begin{array}{l}\text { Saving condition } \\
\text { index }\end{array}$ & $\begin{array}{l}\text { Maintenance } \\
\text { year/accidental }\end{array}$ & $\begin{array}{l}\text { Computation basing on } \\
\text { the maintenance year }\end{array}$ & $\begin{array}{l}\text { Result }(\$) \\
\text { Case study } 1\end{array}$ & $\begin{array}{l}\text { Result (\$) } \\
\text { Case study } 2 \\
\end{array}$ & $\begin{array}{l}\text { Result (\$) } \\
\text { Case study } 3\end{array}$ & $\begin{array}{l}\text { Result }(\$) \\
\text { Case study } 4\end{array}$ \\
\hline Saving in Index 85 & 3.3 & $\left(\sum_{i=1990}^{1992} F I_{i}\right)+\left(\left(F I_{1993}\right) \times\left(\frac{4}{12}\right)\right)$ & 466.66 & 533.3 & 266.67 & 1433.33 \\
\hline Saving in Index 70 & 6.6 & $\left(\sum_{i=1990}^{1995} F I_{i}\right)+\left(\left(F I_{1996}\right) \times\left(\frac{6}{12}\right)\right)$ & 6858.30 & 7733.3 & 3658.30 & 19091.67 \\
\hline Saving in Index 55 & 9.9 & $\left(\sum_{i=1990}^{1998} F I_{i}\right)+\left(\left(F I_{1999}\right) \times\left(\frac{11}{12}\right)\right)$ & 16625.00 & 19275.0 & 10016.67 & 44675.00 \\
\hline Saving in Index 40 & 13.2 & $\left(\sum_{i=1990}^{2002} F I_{i}\right)+\left(\left(F I_{2003}\right) \times\left(\frac{2}{12}\right)\right)$ & 30083.33 & 34500.0 & 18283.30 & 76966.67 \\
\hline Saving in Index 25 & 16.5 & $\left(\sum_{i=1990}^{2005} F I_{i}\right)+\left(\left(F I_{2006}\right) \times\left(\frac{6}{12}\right)\right)$ & 46900.00 & 54250.0 & 29550.00 & 116600.00 \\
\hline Saving in Index 10 & 20.0 & $\left(\sum_{i=1990}^{2009} F I_{i}\right)$ & 63200.00 & 79100.0 & 45350.00 & 167200.00 \\
\hline
\end{tabular}


The predictive data is verified by historical data based on the past 20 years. Second column of Table 6 (maintenance year-historical data) shows that the period of 20 years is divided into six parts based on the CCG system. These data are accidental for verification of predictive data and prediction process during future years. The computation of saving estimate is done based on the maintenance year in each condition index. For example in Table 6 , in the fifth row (index 25) the saving is equal to sum of the financial information of historical data (Table 5) from 1990 to 2005 (16 years) plus 6/12 of $2006(5 / 10=6 / 12)$.

Step 2 is presentation of replacement cost data in the past 20 years (Table 7). The unit replacement cost is according to the current price of cast iron pipe in the Iran's market.

Table 7. Computation replacement cost estimate in situation of historical data

\begin{tabular}{|c|c|c|c|c|c|c|c|c|c|c|}
\hline & Year & $\begin{array}{l}\text { Annual } \\
\text { maintenance } \\
\text { cost }(\$)\end{array}$ & Year & $\begin{array}{l}\text { Annual } \\
\text { maintenance } \\
\text { cost }(\$)\end{array}$ & Year & $\begin{array}{l}\text { Annual } \\
\text { maintenance } \\
\text { cost }(\$)\end{array}$ & Year & $\begin{array}{l}\text { Annual } \\
\text { maintenance } \\
\text { cost }(\$)\end{array}$ & Year & $\begin{array}{l}\text { Annual } \\
\text { maintenance } \\
\text { cost }(\$)\end{array}$ \\
\hline \multirow[t]{4}{*}{ Case Study 1} & 1990 & 2961.511 & 1994 & 6140.991 & 1998 & 12733.959 & 2002 & 22638.150 & 2006 & 34126.000 \\
\hline & 1991 & 3553.814 & 1995 & 7369.189 & 1999 & 15280.750 & 2003 & 25153.500 & 2007 & 53232.500 \\
\hline & 1992 & 4264.577 & 1996 & 8843.027 & 2000 & 18336.901 & 2004 & 27505.500 & 2008 & 58555.750 \\
\hline & 1993 & 5117.492 & 1997 & 10611.632 & 2001 & 20374.335 & 2005 & 31913.000 & 2009 & 64411.325 \\
\hline \multirow[t]{4}{*}{ Case Study 2} & 1990 & 3421.657 & 1994 & 7095.148 & 1998 & 14712.500 & 2002 & 26134.650 & 2006 & 39403.000 \\
\hline & 1991 & 4105.988 & 1995 & 8514.178 & 1999 & 17655.000 & 2003 & 29038.500 & 2007 & 61400.000 \\
\hline & 1992 & 4927.186 & 1996 & 10217.013 & 2000 & 21186.000 & 2004 & 31755.000 & 2008 & 67540.000 \\
\hline & 1993 & 5912.623 & 1997 & 12260.416 & 2001 & 23521.000 & 2005 & 36849.000 & 2009 & 74294.000 \\
\hline \multirow[t]{4}{*}{ Case Study 3} & 1990 & 2991.476 & 1994 & 6203.125 & 1998 & 12862.800 & 2002 & 22867.200 & 2006 & 34417.500 \\
\hline & 1991 & 3589.771 & 1995 & 7443.750 & 1999 & 15435.360 & 2003 & 25408.000 & 2007 & 53910.000 \\
\hline & 1992 & 4307.725 & 1996 & 8932.500 & 2000 & 18522.432 & 2004 & 27778.500 & 2008 & 59301.000 \\
\hline & 1993 & 5169.270 & 1997 & 10719.000 & 2001 & 20580.480 & 2005 & 32192.500 & 2009 & 65231.100 \\
\hline \multirow[t]{4}{*}{ Case Study 4} & 1990 & 9797.495 & 1994 & 20316.085 & 1998 & 42127.435 & 2002 & 76461.300 & 2006 & 115007.000 \\
\hline & 1991 & 11756.994 & 1995 & 24379.302 & 1999 & 50552.922 & 2003 & 84957.000 & 2007 & 179970.000 \\
\hline & 1992 & 14108.392 & 1996 & 29255.163 & 2000 & 63191.157 & 2004 & 92890.000 & 2008 & 197967.000 \\
\hline & 1993 & 16930.071 & 1997 & 35106.195 & 2001 & 69510.273 & 2005 & 107641.000 & 2009 & 217763.700 \\
\hline
\end{tabular}

Table 8. Computation of repair cost estimate in situation of historical data

\begin{tabular}{|c|c|c|c|c|c|}
\hline & Replacement cost $(\$)$ & Index & Maintenance year & Calculation & Repair cost $(\$)$ \\
\hline \multicolumn{6}{|l|}{ Case Study 1} \\
\hline & 4264.577 & 85 & 3.3 & $4264.577 \times((100-85) /(100-10))$ & 710.762 \\
\hline & 7369.189 & 70 & 6.6 & $7369.189 \times((100-70) /(100-10))$ & 2456.396 \\
\hline & 12733.959 & 55 & 9.9 & $12733.959 \times((100-55) /(100-10))$ & 6366.979 \\
\hline & 22638.150 & 40 & 13.2 & $22638.15 \times((100-40) /(100-10))$ & 15092.100 \\
\hline & 31913.000 & 25 & 16.5 & $31913 \times((100-25) /(100-10))$ & 26594.166 \\
\hline & 64411.325 & 10 & 20.0 & $64411.325 \times((100-10) /(100-10))$ & 64411.325 \\
\hline \multicolumn{6}{|l|}{ Case Study 2} \\
\hline & 4927.186 & 85 & 3.3 & $4927.186 \times((100-85) /(100-10))$ & 821.200 \\
\hline & 8514.178 & 70 & 6.6 & $8514.178 \times((100-70) /(100-10))$ & 2838.600 \\
\hline & 14712.500 & 55 & 9.9 & $14712.5 \times((100-55) /(100-10))$ & 7356250.000 \\
\hline & 26134.650 & 40 & 13.2 & $26134.65 \times((100-40) /(100-10))$ & 17423.100 \\
\hline & 36849.000 & 25 & 16.5 & $36849 \times((100-25) /(100-10))$ & 30707.500 \\
\hline & 74294.000 & 10 & 20.0 & $74294 \times((100-10) /(100-10))$ & 74294.000 \\
\hline \multicolumn{6}{|l|}{ Case Study 3} \\
\hline & 4307.725 & 85 & 3.3 & $4307.725 \times((100-85) /(100-10))$ & 717.950 \\
\hline & 7443.750 & 70 & 6.6 & $7443.75 \times((100-70) /(100-10))$ & 2481.250 \\
\hline & 12862.800 & 55 & 9.9 & $12862.8 \times((100-55) /(100-10))$ & 6431.400 \\
\hline & 22867.200 & 40 & 13.2 & $22867.2 \times((100-40) /(100-10))$ & 15244.800 \\
\hline & 32192.500 & 25 & 16.5 & $32192.5 \times((100-25) /(100-10))$ & 26827.100 \\
\hline & 65231.100 & 10 & 20.0 & $65231.1 \times((100-10) /(100-10))$ & 65231.100 \\
\hline \multicolumn{6}{|l|}{ Case Study 4} \\
\hline & 14108.392 & 85 & 3.3 & $14108.392 \times((100-85) /(100-10))$ & 2351.398 \\
\hline & 24379.302 & 70 & 6.6 & $24379.302 \times((100-70) /(100-10))$ & 8126.434 \\
\hline & 42127.435 & 55 & 9.9 & $42127.435 \times((100-55) /(100-10))$ & 21063.717 \\
\hline & 76461.300 & 40 & 13.2 & $76461.3 \times((100-40) /(100-10))$ & 50974.200 \\
\hline & 107641.000 & 25 & 16.5 & $107641 \times((100-25) /(100-10))$ & 89700.833 \\
\hline & 217763.700 & 10 & 20.0 & $217763.7 \times((100-10) /(100-10))$ & 217763.700 \\
\hline
\end{tabular}


The replacement cost is calculated based on dimension of waste-water plumbing system (size and length) of case studies, price of cast iron pipe in the Iran's market.

Step 3 is calculation of repair cost estimate to achieve the cost data in BCR (Table 8). Repair cost is computed based on standard Equation 4. Between these condition index scales a parametric model of component repair cost is described as a comprehensive estimation of the corrective repair cost as a percentage of the total replacement cost in waste-water plumbing system of case studies.

Table 9 and Fig. 3 depict the analysis of optimum maintenance management of cast iron pipe in wastewater plumbing system for case studies based on a period of 20 years.

\section{Analysis of Predictive Data}

Table 10 shows the financial predictive data for case studies. The predictive data is selected based on period of 50 years that corresponds to the useful lifespan of cast iron pipe which is approximately 50 years using the prediction process and the average inflation rate computed from 1990 to 2009 (historical data) (Table 5).

This information is based on existing historical documents in case studies.

Table 11 presents the calculation of financial predictive data to achieve the saving estimate. For example in Table 11, in the second row (index 70) the saving is equal to sum of the financial information of predictive data (Table 10) from 2011 to 2026 (16 years) plus $11 / 12$ of $2027(9 / 10 \approx 11 / 12)$.

Table 12 is calculation of replacement cost data for the future 50. The predictive data of replacement cost is calculated with inflation rate of $8 \%$ based on average inflation rate of cast iron pipe in Iran's market from 2000 to 2010 (Index Mundi, 2011).

Table 13 presents the calculation of repair cost estimate to achieve the investment information.

Table 14 and Fig. 4 depict the analysis of optimum maintenance management of cast iron pipe in waste water plumbing system for case studies based on a period of 50 years.

\section{Stage 3: Verification of Data Analysis}

Verification of data analysis is concerned with identifying historical data in the model by comparing historical data and predictive data to analytical or workable capability for process. Verification of analysis process is required when a predictive process is the end product. The workable process must then reflect the strength of the inference being made from the historical database to the prediction. The verification of data analysis process is motivated by the need for practical process for making predictions to support the maintenance management process and by the current lack of guidelines, standards and procedures for performing model.

Table 9. Financial analysis of historical data

\begin{tabular}{|c|c|c|c|c|c|}
\hline & CCG index & Maintenance year & Cost estimation $(\$)$ & Saving estimation $(\$)$ & $\mathrm{BCR}$ \\
\hline \multicolumn{6}{|l|}{ Case Study 1} \\
\hline & 85 & 3.3 & 710.762 & 466.66 & 0.66 \\
\hline & 70 & 6.6 & 2456.396 & 6858.30 & 2.79 \\
\hline & 55 & 9.9 & 6366.979 & 16625.00 & 2.61 \\
\hline & 40 & 13.2 & 15092.100 & 30083.33 & 1.99 \\
\hline & 25 & 16.5 & 26594.166 & 46900.00 & 1.76 \\
\hline & 10 & 20.0 & 64411.325 & 63200.00 & 1.05 \\
\hline \multicolumn{6}{|l|}{ Case Study 2} \\
\hline & 85 & 3.3 & 821.200 & 533.30 & 0.65 \\
\hline & 70 & 6.6 & 2838.600 & 7733.30 & 2.72 \\
\hline & 55 & 9.9 & 7356250.000 & 19275.00 & 2.62 \\
\hline & 40 & 13.2 & 17423.100 & 34500.00 & 1.98 \\
\hline & 25 & 16.5 & 30707.500 & 54250.00 & 1.77 \\
\hline & 10 & 20.0 & 74294.000 & 79100.00 & 1.06 \\
\hline \multicolumn{6}{|c|}{ Case Study 3} \\
\hline & 85 & 3.3 & 717.950 & 266.67 & 0.37 \\
\hline & 70 & 6.6 & 2481.250 & 3658.30 & 1.47 \\
\hline & 55 & 9.9 & 6431.400 & 10016.67 & 1.56 \\
\hline & 40 & 13.2 & 15244.800 & 18283.30 & 1.20 \\
\hline & 25 & 16.5 & 26827.100 & 29550.00 & 1.10 \\
\hline & 10 & 20.0 & 65231.100 & 45350.00 & 0.70 \\
\hline \multicolumn{6}{|l|}{ Case Study 4} \\
\hline & 85 & 3.3 & 2351.398 & 1433.33 & 0.61 \\
\hline & 70 & 6.6 & 8126.434 & 19091.67 & 2.35 \\
\hline & 55 & 9.9 & 21063.717 & 44675.00 & 2.12 \\
\hline & 40 & 13.2 & 50974.200 & 76966.67 & 1.51 \\
\hline & 25 & 16.5 & 89700.833 & 116600.00 & 1.30 \\
\hline & 10 & 20.0 & 217763.700 & 167200.00 & 0.77 \\
\hline
\end{tabular}


Nima Amani / American Journal of Engineering and Applied Sciences 2016, 9 (2): 281.296 DOI: 10.3844/ajeassp.2016.281.296

\begin{tabular}{|c|c|c|c|c|c|c|c|c|c|c|}
\hline & Year & $\begin{array}{l}\text { Annual } \\
\text { maintenance } \\
\text { cost }(\$)\end{array}$ & Year & $\begin{array}{l}\text { Annual } \\
\text { maintenance } \\
\text { cost }(\$)\end{array}$ & Year & $\begin{array}{l}\text { Annual } \\
\text { maintenance } \\
\text { cost }(\$)\end{array}$ & Year & $\begin{array}{l}\text { Annual } \\
\text { maintenance } \\
\text { cost }(\$)\end{array}$ & Year & $\begin{array}{l}\text { Annual } \\
\text { maintenance } \\
\text { cost }(\$)\end{array}$ \\
\hline \multicolumn{11}{|l|}{ Case study 1} \\
\hline & 2011 & - & 2021 & 9100 & 2031 & 13800 & 2041 & 20500 & 2051 & 30400 \\
\hline & 2012 & - & 2022 & 9500 & 2032 & 14400 & 2042 & 21300 & 2052 & 31600 \\
\hline & 2013 & - & 2023 & 9900 & 2033 & 15000 & 2043 & 22200 & 2053 & 32900 \\
\hline & 2014 & - & 2024 & 10300 & 2034 & 15600 & 2044 & 23100 & 2054 & 34200 \\
\hline & 2015 & - & 2025 & 10800 & 2035 & 16200 & 2045 & 24000 & 2055 & 35600 \\
\hline & 2016 & - & 2026 & 11300 & 2036 & 16800 & 2046 & 25000 & 2056 & 37000 \\
\hline & 2017 & - & 2027 & 11800 & 2037 & 17500 & 2047 & 26000 & 2057 & 38500 \\
\hline & 2018 & 7900 & 2028 & 12300 & 2038 & 18200 & 2048 & 27000 & 2058 & 40000 \\
\hline & 2019 & 8300 & 2029 & 12800 & 2039 & 18900 & 2049 & 28100 & 2059 & 41600 \\
\hline & 2020 & 8700 & 2030 & 13300 & 2040 & 19700 & 2050 & 29200 & 2060 & 43300 \\
\hline \multicolumn{11}{|l|}{ Case study 2} \\
\hline & 2011 & - & 2021 & 12200 & 2031 & 19800 & 2041 & 32200 & 2051 & 52700 \\
\hline & 2012 & - & 2022 & 12800 & 2032 & 20800 & 2042 & 33800 & 2052 & 55300 \\
\hline & 2013 & - & 2023 & 13400 & 2033 & 21800 & 2043 & 35500 & 2053 & 58100 \\
\hline & 2014 & - & 2024 & 14100 & 2034 & 22900 & 2044 & 37300 & 2054 & 61000 \\
\hline & 2015 & - & 2025 & 14800 & 2035 & 24000 & 2045 & 39200 & 2055 & 64100 \\
\hline & 2016 & - & 2026 & 15500 & 2036 & 25200 & 2046 & 41200 & 2056 & 67300 \\
\hline & 2017 & - & 2027 & 16300 & 2037 & 26500 & 2047 & 43300 & 2057 & 70700 \\
\hline & 2018 & 10500 & 2028 & 17100 & 2038 & 27800 & 2048 & 45500 & 2058 & 74200 \\
\hline & 2019 & 11000 & 2029 & 18000 & 2039 & 29200 & 2049 & 47800 & 2059 & 77900 \\
\hline & 2020 & 11600 & 2030 & 18900 & 2040 & 30700 & 2050 & 50200 & 2060 & 81800 \\
\hline \multicolumn{11}{|l|}{ Case study 3} \\
\hline & 2011 & - & 2021 & 10700 & 2031 & 23300 & 2041 & 50300 & 2051 & 108600 \\
\hline & 2012 & - & 2022 & 11600 & 2032 & 25100 & 2042 & 54300 & 2052 & 117300 \\
\hline & 2013 & - & 2023 & 12500 & 2033 & 27100 & 2043 & 58600 & 2053 & 126600 \\
\hline & 2014 & - & 2024 & 13500 & 2034 & 29300 & 2044 & 63300 & 2054 & 136800 \\
\hline & 2015 & - & 2025 & 14600 & 2035 & 31700 & 2045 & 68400 & 2055 & 147700 \\
\hline & 2016 & - & 2026 & 15800 & 2036 & 34200 & 2046 & 73900 & 2056 & 159600 \\
\hline & 2017 & - & 2027 & 17100 & 2037 & 36900 & 2047 & 79800 & 2057 & 172300 \\
\hline & 2018 & - & 2028 & 18500 & 2038 & 39900 & 2048 & 86200 & 2058 & 186100 \\
\hline & 2019 & - & 2029 & 19900 & 2039 & 43100 & 2049 & 93100 & 2059 & 201000 \\
\hline & 2020 & - & 2030 & 21500 & 2040 & 46500 & 2050 & 100500 & 2060 & 217100 \\
\hline \multicolumn{7}{|l|}{ Case study 4} & & & & 185100 \\
\hline & 2012 & - & 2022 & 34100 & 2032 & 61100 & 2042 & 109500 & 2052 & 196200 \\
\hline & 2013 & - & 2023 & 36200 & 2033 & 64800 & 2043 & 116100 & 2053 & 208000 \\
\hline & 2014 & - & 2024 & 38300 & 2034 & 68700 & 2044 & 123100 & 2054 & 220500 \\
\hline & 2015 & - & 2025 & 40600 & 2035 & 72800 & 2045 & 130500 & 2055 & 233700 \\
\hline & 2016 & - & 2026 & 43100 & 2036 & 77200 & 2046 & 138300 & 2056 & 247700 \\
\hline & 2017 & - & 2027 & 45700 & 2037 & 81800 & 2047 & 146600 & 2057 & 262600 \\
\hline & 2018 & 27000 & 2028 & 48400 & 2038 & 86800 & 2048 & 155400 & 2058 & 278300 \\
\hline & 2019 & 28600 & 2029 & 51300 & 2039 & 92000 & 2049 & 164700 & 2059 & 295000 \\
\hline & 2020 & 30400 & 2030 & 54400 & 2040 & 97500 & 2050 & 174600 & 2060 & 312700 \\
\hline
\end{tabular}

Table 11. Computation of saving estimate in situation of predictive data

Predictive data

\begin{tabular}{|c|c|c|c|c|c|c|}
\hline $\begin{array}{l}\text { Saving Condition } \\
\text { Index }\end{array}$ & $\begin{array}{l}\text { Maintenance } \\
\text { Year }\end{array}$ & $\begin{array}{l}\text { Computation basing on the } \\
\text { Maintenance Year }\end{array}$ & $\begin{array}{l}\text { Result }(\$) \\
\text { Case study } 1\end{array}$ & $\begin{array}{l}\text { Result }(\$) \\
\text { Case -study } 2\end{array}$ & $\begin{array}{l}\text { Result }(\$) \\
\text { Case study } 3\end{array}$ & $\begin{array}{l}\text { Result }(\$) \\
\text { Case study } 4\end{array}$ \\
\hline Saving in Index 85 & 9.0 & $\sum_{i=2011}^{2017} \mathrm{FI}_{i}$ & 16200.00 & 21500.00 & 0 & 55600.00 \\
\hline Saving in Index 70 & 16.9 & $\left(\sum_{i=2011}^{2026} F I_{i}\right)+\left(\left(F I_{2027}\right) \times\left(\frac{11}{12}\right)\right)$ & 96616.66 & 130841.67 & 94375 & 352391.66 \\
\hline Saving in Index 55 & 26.5 & $\left(\sum_{i=2011}^{2036} F I_{i}\right)+\left(\left(F I_{2037}\right) \times\left(\frac{6}{12}\right)\right)$ & 236550.00 & 333950.00 & 344850 & 953500.00 \\
\hline Saving in Index 40 & 36.1 & $\left(\sum_{i=2011}^{2046} F I_{i}\right)+\left(\left(F I_{2047}\right) \times\left(\frac{1}{12}\right)\right)$ & 440366.66 & 657708.30 & 868250 & 2003716.66 \\
\hline Saving in Index 25 & 43.9 & $\left(\sum_{i=2011}^{2053} F I_{i}\right)+\left(\left(F I_{2054}\right) \times\left(\frac{11}{12}\right)\right)$ & 674750.00 & 1062916.67 & 1699100 & 3424225.00 \\
\hline Saving in Index 10 & 50.0 & $\left(\sum_{i=2011} F I_{i}\right)$ & 913600.00 & 1504000.00 & 2794300 & 5072600.00 \\
\hline
\end{tabular}


Nima Amani / American Journal of Engineering and Applied Sciences 2016, 9 (2): 281.296 DOI: 10.3844/ajeassp.2016.281.296

\begin{tabular}{|c|c|c|c|c|c|c|c|c|c|c|}
\hline & Year & $\begin{array}{l}\text { Replacement } \\
\text { cost }(\$)\end{array}$ & Year & $\begin{array}{l}\text { Replacement } \\
\text { cost }(\$)\end{array}$ & Year & $\begin{array}{l}\text { Replacement } \\
\text { cost }(\$)\end{array}$ & Year & $\begin{array}{l}\text { Replacement } \\
\text { cost }(\$)\end{array}$ & Year & $\begin{array}{l}\text { Replacement } \\
\text { cost }(\$)\end{array}$ \\
\hline \multicolumn{11}{|l|}{ Case study 1} \\
\hline & 2011 & 66725 & 2021 & 144054 & 2031 & 311002 & 2041 & 671430 & 2051 & 1449568 \\
\hline & 2012 & 72063 & 2022 & 155578 & 2032 & 335882 & 2042 & 725145 & 2052 & 1565534 \\
\hline & 2013 & 77828 & 2023 & 168024 & 2033 & 362753 & 2043 & 783156 & 2053 & 1690776 \\
\hline & 2014 & 84054 & 2024 & 181466 & 2034 & 391773 & 2044 & 845809 & 2054 & 1826039 \\
\hline & 2015 & 90778 & 2025 & 195984 & 2035 & 423115 & 2045 & 913474 & 2055 & 1972122 \\
\hline & 2016 & 98040 & 2026 & 211662 & 2036 & 456964 & 2046 & 986552 & 2056 & 2129891 \\
\hline & 2017 & 105884 & 2027 & 228596 & 2037 & 493521 & 2047 & 1065476 & 2057 & 2300283 \\
\hline & 2018 & 114354 & 2028 & 246883 & 2038 & 533003 & 2048 & 1150714 & 2058 & 2484306 \\
\hline & 2019 & 123503 & 2029 & 266634 & 2039 & 575643 & 2049 & 1242771 & 2059 & 2683050 \\
\hline & 2020 & 133383 & 2030 & 287965 & 2040 & 621695 & 2050 & 1342193 & 2060 & 2897694 \\
\hline \multicolumn{11}{|l|}{ Case study 2} \\
\hline & 2011 & 76375 & 2021 & 164887 & 2031 & 355980 & 2041 & 768535 & 2051 & 1659210 \\
\hline & 2012 & 82485 & 2022 & 178078 & 2032 & 384459 & 2042 & 830018 & 2052 & 1791947 \\
\hline & 2013 & 89083 & 2023 & 192325 & 2033 & 415215 & 2043 & 896419 & 2053 & 1935302 \\
\hline & 2014 & 96210 & 2024 & 207711 & 2034 & 448433 & 2044 & 968133 & 2054 & 2090127 \\
\hline & 2015 & 103907 & 2025 & 224328 & 2035 & 484307 & 2045 & 1045583 & 2055 & 2257337 \\
\hline & 2016 & 112219 & 2026 & 242274 & 2036 & 523052 & 2046 & 1129230 & 2056 & 2437924 \\
\hline & 2017 & 121197 & 2027 & 261656 & 2037 & 564896 & 2047 & 1219569 & 2057 & 2632958 \\
\hline & 2018 & 130893 & 2028 & 282588 & 2038 & 610088 & 2048 & 1317134 & 2058 & 2843594 \\
\hline & 2019 & 141364 & 2029 & 305195 & 2039 & 658895 & 2049 & 1422505 & 2059 & 3071082 \\
\hline & 2020 & 152673 & 2030 & 329611 & 2040 & 711606 & 2050 & 1536305 & 2060 & 3316769 \\
\hline \multicolumn{11}{|l|}{ Case study 3} \\
\hline & 2011 & 68950 & 2021 & 148857 & 2031 & 321372 & 2041 & 693820 & 2051 & 1497905 \\
\hline & 2012 & 74466 & 2022 & 160766 & 2032 & 347082 & 2042 & 749325 & 2052 & 1617738 \\
\hline & 2013 & 80423 & 2023 & 173627 & 2033 & 374849 & 2043 & 809271 & 2053 & 1747157 \\
\hline & 2014 & 86857 & 2024 & 187518 & 2034 & 404837 & 2044 & 874013 & 2054 & 1886929 \\
\hline & 2015 & 93805 & 2025 & 202519 & 2035 & 437224 & 2045 & 943934 & 2055 & 2037884 \\
\hline & 2016 & 101310 & 2026 & 218721 & 2036 & 472202 & 2046 & 1019449 & 2056 & 2200914 \\
\hline & 2017 & 109414 & 2027 & 236218 & 2037 & 509978 & 2047 & 1101005 & 2057 & 2376988 \\
\hline & 2018 & 118168 & 2028 & 255116 & 2038 & 550776 & 2048 & 1189085 & 2058 & 2567147 \\
\hline & 2019 & 127621 & 2029 & 275525 & 2039 & 594838 & 2049 & 1284212 & 2059 & 2772519 \\
\hline & 2020 & 137831 & 2030 & 297567 & 2040 & 642426 & 2050 & 1386949 & 2060 & 2994320 \\
\hline \multicolumn{11}{|l|}{ Case study 4} \\
\hline & 2011 & 223450 & 2021 & 482411 & 2031 & 1041490 & 2041 & 2248500 & 2051 & 4854344 \\
\hline & 2012 & 241326 & 2022 & 521004 & 2032 & 1124810 & 2042 & 2428380 & 2052 & 5242691 \\
\hline & 2013 & 260632 & 2023 & 562685 & 2033 & 1214794 & 2043 & 2622651 & 2053 & 5662107 \\
\hline & 2014 & 281482 & 2024 & 607699 & 2034 & 1311978 & 2044 & 2832463 & 2054 & 6115075 \\
\hline & 2015 & 304001 & 2025 & 656315 & 2035 & 1416936 & 2045 & 3059060 & 2055 & 6604281 \\
\hline & 2016 & 328321 & 2026 & 708821 & 2036 & 1530291 & 2046 & 3303785 & 2056 & 7132624 \\
\hline & 2017 & 354587 & 2027 & 765526 & 2037 & 1652715 & 2047 & 3568087 & 2057 & 7703234 \\
\hline & 2018 & 382954 & 2028 & 826769 & 2038 & 1784932 & 2048 & 3853535 & 2058 & 8319493 \\
\hline & 2019 & 413590 & 2029 & 892910 & 2039 & 1927726 & 2049 & 4161817 & 2059 & 8985052 \\
\hline & 2020 & 446677 & 2030 & 964343 & 2040 & 2081945 & 2050 & 4494763 & 2060 & 9703856 \\
\hline
\end{tabular}

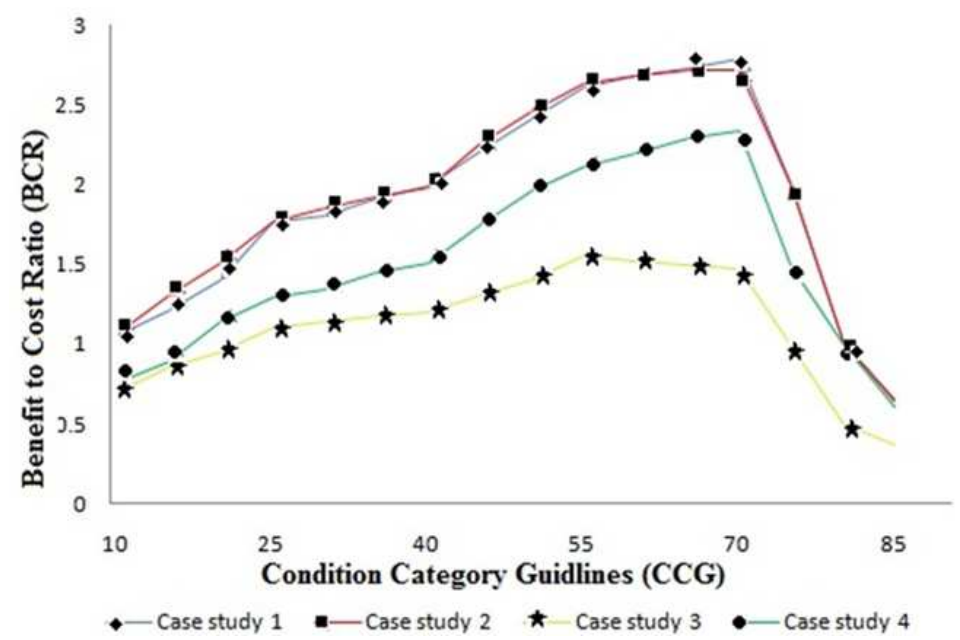

Fig. 3. Optimum facilities maintenance time based on highest BCR (historical data) 
Nima Amani / American Journal of Engineering and Applied Sciences 2016, 9 (2): 281.296 DOI: 10.3844/ajeassp.2016.281.296

Table 13. Computation of repair cost estimate in situation of predictive data

\begin{tabular}{lrrrrr}
\hline & \multicolumn{1}{l}{$\begin{array}{l}\text { Replacement } \\
\text { Cost }(\$)\end{array}$} & $\begin{array}{l}\text { Maintenance } \\
\text { index }\end{array}$ & Year & Calculation & Repair Cost (\$) \\
\hline Case study 1 & & & & & \\
& 123503 & 85 & 9.0 & $123503 \times((100-85) /(100-10))$ & 20583.83 \\
& 211662 & 70 & 16.9 & $211662 \times((100-70) /(100-10))$ & 70554.00 \\
& 456964 & 55 & 26.5 & $430769 \times((100-55) /(100-10))$ & 228482.00 \\
& 986552 & 40 & 36.1 & $456964 \times((100-40) /(100-10))$ & 657701.33 \\
& 1690776 & 25 & 43.9 & $1690776 \times((100-25) /(100-10))$ & 1408980.00 \\
Case study 2 & 2897694 & 10 & 50.0 & $2897694 \times((100-10) /(100-10))$ & 2897694.00 \\
& & & & & \\
& 141364 & 85 & 9.0 & $141364 \times((100-85) /(100-10))$ & 23560.67 \\
& 242274 & 70 & 16.9 & $242274 \times((100-70) /(100-10))$ & 80758.00 \\
& 523052 & 55 & 26.5 & $523052 \times((100-55) /(100-10))$ & 261526.00 \\
& 1129230 & 40 & 36.1 & $1129230 \times((100-40) /(100-10))$ & 752820.00 \\
& 1935302 & 25 & 43.9 & $1935302 \times((100-25) /(100-10))$ & 1612751.67 \\
& 3316769 & 10 & 50.0 & $3316769 \times((100-10) /(100-10))$ & 3316769.00 \\
& & & & \\
& 127621 & 85 & 9.0 & $127621 \times((100-85) /(100-10))$ & 21270.17 \\
& 218721 & 70 & 16.9 & $218721 \times((100-70) /(100-10))$ & 72907.00 \\
& 472202 & 55 & 26.5 & $472202 \times((100-55) /(100-10))$ & 236101.00 \\
& 1019449 & 40 & 36.1 & $1019449 \times((100-40) /(100-10))$ & 679632.67 \\
& 1747157 & 25 & 43.9 & $1747157 \times((100-25) /(100-10))$ & 1455964.17 \\
& 2994320 & 10 & 50.0 & $2994320 \times((100-10) /(100-10))$ & 2994320.00 \\
& & & & \\
& 413590 & 85 & 9.0 & $413590 \times((100-85) /(100-10))$ & 68931.67 \\
& 708821 & 70 & 16.9 & $708821 \times((100-70) /(100-10))$ & 236273.67 \\
& 1530291 & 55 & 26.5 & $1530291 \times((100-55) /(100-10))$ & 765145.50 \\
& 3303785 & 40 & 36.1 & $3303785 \times((100-40) /(100-10))$ & 2202523.33 \\
& 5662107 & 25 & 43.9 & $5662107 \times((100-25) /(100-10))$ & 4718422.50 \\
& 9703856 & 10 & 50.0 & $9703856 \times((100-10) /(100-10))$ & 9703856.00 \\
\hline
\end{tabular}

Table 14. Financial analysis of predictive data

\begin{tabular}{|c|c|c|c|c|c|}
\hline & CCG index & $\begin{array}{l}\text { Maintenance } \\
\text { year }\end{array}$ & $\begin{array}{l}\text { Cost } \\
\text { estimation (\$) }\end{array}$ & $\begin{array}{l}\text { Saving } \\
\text { estimation }(\$)\end{array}$ & $\mathrm{BCR}$ \\
\hline \multicolumn{6}{|l|}{ Case Study 1} \\
\hline & 85 & 9.0 & 20583.83 & 16200.00 & 0.79 \\
\hline & 70 & 16.9 & 70554.00 & 96616.66 & 1.37 \\
\hline & 55 & 26.5 & 228482.00 & 236550.00 & 1.04 \\
\hline & 40 & 36.1 & 657701.33 & 440366.66 & 0.67 \\
\hline & 25 & 43.9 & 1408980.00 & 674750.00 & 0.48 \\
\hline & 10 & 50.0 & 2897694.00 & 913600.00 & 0.32 \\
\hline \multicolumn{6}{|l|}{ Case Study 2} \\
\hline & 85 & 9.0 & 23560.67 & 21500.00 & 0.91 \\
\hline & 70 & 16.9 & 80758.00 & 130841.67 & 1.62 \\
\hline & 55 & 26.5 & 261526.00 & 333950.00 & 1.28 \\
\hline & 40 & 36.1 & 752820.00 & 657708.3 & 0.87 \\
\hline & 25 & 43.9 & 1612751.67 & 1062916.67 & 0.66 \\
\hline & 10 & 50.0 & 3316769.00 & 1504000.00 & 0.45 \\
\hline \multicolumn{6}{|l|}{ Case Study 3} \\
\hline & 85 & 9.0 & 21270.17 & 0.00 & 0.00 \\
\hline & 70 & 16.9 & 72907.00 & 94375.00 & 1.29 \\
\hline & 55 & 26.5 & 236101.00 & 344850.00 & 1.46 \\
\hline & 40 & 36.1 & 679632.67 & 868250.00 & 1.28 \\
\hline & 25 & 43.9 & 1455964.17 & 1699100.00 & 1.17 \\
\hline & 10 & 50.0 & 2994320.00 & 2794300.00 & 0.93 \\
\hline \multicolumn{6}{|l|}{ Case Study 4} \\
\hline & 85 & 9.0 & 68931.67 & 55600.00 & 0.81 \\
\hline & 70 & 16.9 & 236273.67 & 352391.66 & 1.49 \\
\hline & 55 & 26.5 & 765145.50 & 953500.00 & 1.25 \\
\hline & 40 & 36.1 & 2202523.33 & 2003716.66 & 0.91 \\
\hline & 25 & 43.9 & 4718422.50 & 3424225.00 & 0.73 \\
\hline & 10 & 50.0 & 9703856.00 & 5072600.00 & 0.52 \\
\hline
\end{tabular}




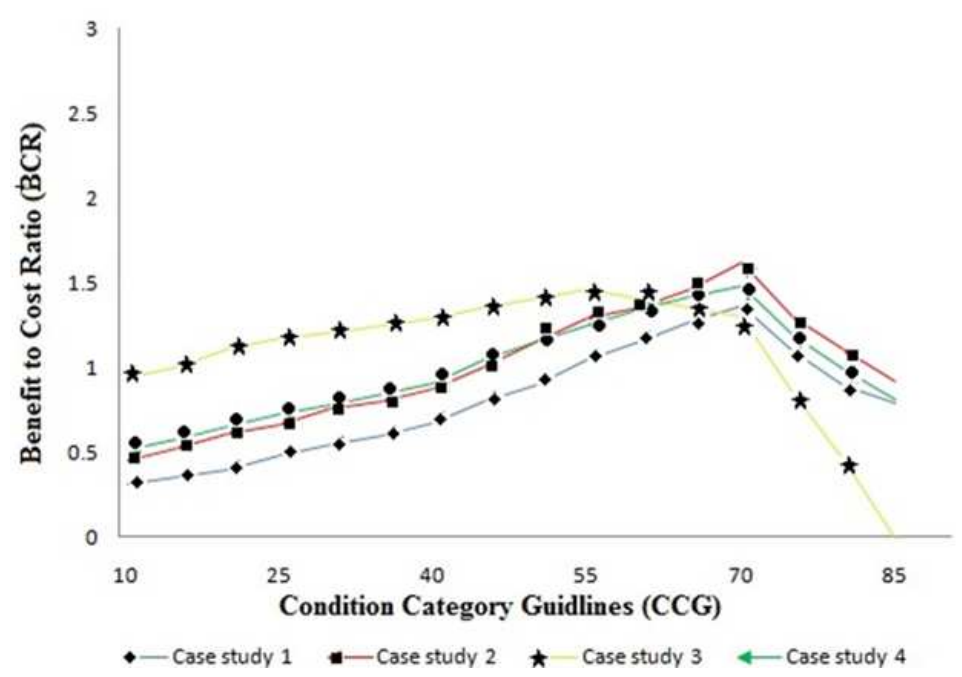

Fig. 4. Optimum facilities maintenance time based on highest BCR (predictive data)

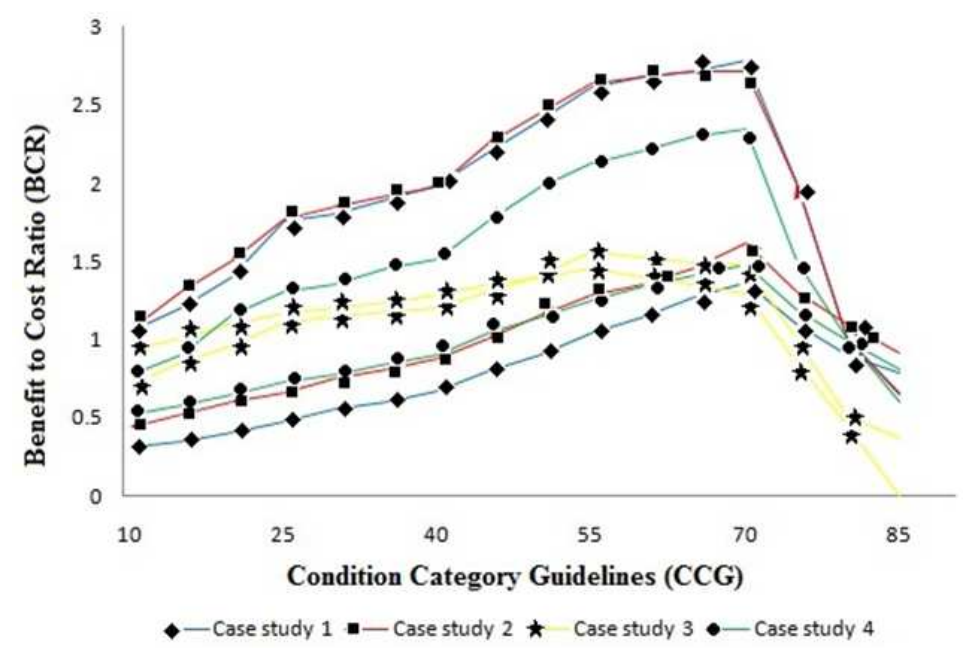

Fig. 5. Verification of data analysis in two situations of historical and predictive data

This information is used to decide whether or not the process has resulted in workable capability with the verification of process in two situations of historical and predictive data. The workable capability decision focuses only on the level of match between the analysis outcome of historical data and predictive data.

Figure 5 illustrates the financial analysis simulation of optimum index based on highest BCR in two situations of historical and predictive data for case studies. The similarity of optimum index in two situations of historical and predictive data shows that this process is acceptable for prediction of maintenance process in waste-water network of case studies.

\section{Discussion}

The process framework was tested in four steps for 4 case studies. These steps were analyzed and simulated in two situations of historical and predictive data for each case-study. The purpose of data analysis in two situations of historical and predictive data was the testing of process. This process is for the prediction of optimum maintenance time of the waste-water network in hotel buildings with respect to the limited cost allocated to the department of component maintenance. If the optimum condition index is the same in two situations of historical and predictive data, it implies the workable capability of the process for accurate prediction in the future. The analysis results show that the process was tested for all case studies one by one.

In the verification of data analysis process, at first, the historical data have been considered and run for each case study and then the predictive data will be run in the process. In the next stage, the simulated results are compared in situations of historical and predictive data together. If the optimum condition 
index and also ascending and descending diagrams of condition indices are the same in two situations of historical and predictive data, it results in a workable process model.

The highest BCR occurs in index 70 for the case studies 1, 2 and 4. This condition index is the same in situations of historical and predictive data (Fig. 5). In referring to Fig. 5 it can be noticed that the ascending and descending diagrams are the same from index 85 to index 10 in two situations of historical and predictive data for all case studies. The diagram traverses an upward trend from index 85 to index 70 and after that traverses a downtrend from index 70 to index 10 for six case studies 1,2 and 4 . This process is the same in both historical and predictive data for these hotels. This process traverses an uptrend from index 85 to index 55 and after that traverses a downtrend from index 55 to index 10 for case study 3 . The optimum index is 55 in both the historical and predictive data for this hotel.

The closeness of the diagrams show that the financial managers present accurate predictions for maintenance costs allocated to future years. Figure 5 illustrates that case study 3 has the most accurate predictive data in the process model analysis. After that, the case studies 4, 2 and 1 are in the next places, respectively, according to the accurateness of predictive data. The results show that the predictive data presented from the financial managers of case study 1 seem to be changed in the future. These changes are because of remoteness of historical and predictive data diagrams. If the agreement between the analysis outcome of historical data and predictive data is unacceptable, the predictive data can be revised. Data revision is the process of changing the cost, or budget allocated to improve agreement with experimental outcomes. The revision process is out of this study area.

The data analysis has been done based on limited (existing) cost of maintenance in waste-water network. Therefore, the amount of maximum BCR is not important in optimum indices. The objective is identification of optimum index based on the highest BCR. The optimum index shows the suitable time of maintenance, service, cleaning, comprehensive inspecting and repairing in waste-water networks of hotels during 50 years. In an economical system, the maximum BCR should be more than 1 and this issue is very important related to the optimization subject (Ruegg and Marshall, 1990). In referring to Fig. 5 it can be found that the maximum BCR is more than 1 for identifying the optimum maintenance time for all case studies.

When the optimum maintenance time was identified and maintenance activities were performed basically, the financial managers can transfer the remaining annual maintenance cost allocated in the waste-water department to other organizations and installation in a building. This cost transmission results in cost optimization in the department of building installation and facilities.

\section{Findings}

In this study, the Maintenance Management Process Analysis (MMPA) was tested for waste-water plumbing system in four case studies during future 50 years. These results illustrate the relationship between maintenance times of waste-water systems and its economical ratio. The results are variable because of the existing costs of maintenance for each hotel individually. Table 15 shows the relationship between BCR and condition index value when the engineers do maintenance in waste-water system for 4 case studies.

The most economical maintenance is when the BCR is highest. Therefore, maintenance of waste-water system in index 70 is most economical in case studies 1 , 2 and 4. For case study 3, the most economical maintenance is in index 55.

The resulted process model is an integrated and comprehensive model that is able to clarify the process of wastewater system maintenance. The strength of the model in the fact that it can provide a detailed wastewater systems evidence of the relationships between maintenance management parameters namely maintenance times and maintenance existing costs. This study will be useful to researchers, maintenance professionals and others concerned with maintenance management of wastewater plumbing systems in hotel building.

Table 15. Optimum management of facilities maintenance using the CCG BCR in hotels

\begin{tabular}{lllll} 
Indices & Maintenance Year & Case study 1 & Case study 2 & Case study 3 \\
\hline 85 & 9.0 & 0.79 & 0.91 & 0.00 \\
70 & 16.9 & 1.37 & 1.62 & 1.29 \\
55 & 26.5 & 1.04 & 1.28 & 1.46 \\
40 & 36.1 & 0.67 & 0.87 & 1.28 \\
25 & 43.9 & 0.48 & 0.66 & 1.25 \\
10 & 50.0 & 0.32 & 0.45 & 0.91 \\
\hline
\end{tabular}




\section{Conclusion}

This research described a new, systematic framework for developing a suitable maintenance process model for wastewater plumbing system in a hotel building. Introducing this process model to building maintenance management is expected both to reduce building maintenance costs and to improve the service life, health and safety of the wastewater systems in hotel building. The proposed process consists of three main steps: (1) Component condition assessment (based on the available information records about component condition) in order to highlight the component that most needs to be assessed as a case study; (2) a comprehensive survey on the existing condition assessment methods of building components in order to identify the appropriate assessment method that can be used to measure building components; and (3) financial computations based on data collected in order to optimize facilities maintenance management in hotel building installations. The framework is focused on a process analysis to optimize building component maintenance time that has limited cost with respect to component condition assessment methods and economical management. The results and findings of the survey described in this study provide a better understanding of prediction mechanisms with respect to the existing resources. This understanding could be the starting point for extensive work related to the maintenance management scenario of the component management system.

\section{Acknowledgement}

The author gratefully acknowledges support provided by the Islamic Azad University, Chalous Branch, Mazandaran, Iran.

\section{Ethics}

The author addresses any ethical issues that may arise after the publication of this manuscript.

\section{References}

Ali, A.S., 2009. Cost decision making in building maintenance practice in Malaysia. J. Facilities Manage., 7: 298-306.

DOI: $10.1108 / 14725960910990044$

Amani, N., M.A. Nasly, A.H. Mohamed and R.A. Samat, 2012. A survey on the facilities maintenance management system implementation in Iran's buildings. Malaysian J. Civil Eng., 24: 85-91.
Arditi, D. and M. Nawakorawit, 1999. Designing buildings for maintenance: property managers' perspective. J. Arch. Eng., 5: 117-132.

Boyle, G., 2003. Design project management. Ashgate, Burlington, NC.

Builder, 2008. BUILDER engineered management system.

Farokhmehr, A., 2009. The condition of Tehran's Hotels.

Index Mundi, 2011. Equivalent data from the international monetary fund. Index Mundi.

Lam, E.W.M., A.P.C. Chan and D.W.M. Chan, 2010. Benchmarking success of building maintenance projects. Facilities, 28: 290-305.

DOI: $10.1108 / 02632771011031529$

Lazarus, W.F., 2012. Machinery cost estimates. University of Minnesota.

Lee, H.H.Y. and D. Scott, 2009. Overview of maintenance strategy, acceptable maintenance standard and resources from a building maintenance operation perspective. J. Build. Appraisal, 4: 269-278.

HOAM, 1993. Estimating useful life for capital assets. HOA Management, Lose Angeles.

RSMC, 2008. Square Foot Costs. 29th Edn., RS Means Company Inc.

Mohd-Noor, N., Y. Hamid, A.A. Ghani and S.N. Haron, 2011. Building maintenance budget determination: An exploration study in the Malaysia government practice. Proccedia Eng., 20: 435-444. DOI: $10.1016 /$ j.proeng.2011.11.186

Price Index, 2011. President deputy strategic planning and control. Price Index.

Ruegg, T.R. and H.E. Marshall, 1990. Building economic: Theory and practice. Van Nostrand Reinhold- VNR, New York.

Sajadi, S.J. and B. Moghadam, 2005. Cost assessment of maintenance and repair in industrial. Proceedings of the 3th National Conference in Maintenance and Repair, (CMR' 05), Tehran, Iran.

TAHU, 2011. Tehran area hotel union.

Tilley, P.A. and S.L. McFallen, 2000. Design and documentation quality survey designer's perspectives. Melbourne, CSIRO.

Uzarski, D.R., 1993. Development of condition indexes for low volume railroad track. USACERL, Champaign, Illinois. 